This Journal is available in Telkom University online Journals

Jurnal Manajemen Indonesia

\title{
Integrating TAM, VAM, PAM and Security Perception in The Intention of Fintech Service Usage
}

\author{
Aglis Andhita Hatmawan ${ }^{1}$, Abdul Rohman Taufiq ${ }^{2}$ \\ Management Department, Faculty of Economy and Business, Universitas PGRI Madiun. \\ Program Studi Akuntansi, Fakultas Ekonomi dan Bisnis Universitas PGRI Madiun
}

\begin{abstract}
This study is meant to develop a TAM (Technology Acceptance Model) by integrating a VAM (Value-based Adoption Model), PAM (Pos Acceptance Model) and security perceptions. The frameworks of the theories are expected to deeper explain the perspective perceived by fintech services users in terms of security, perceived value, benefits, and satisfaction in using fintech. Survey through a quantitative approach combined with explanatory research in Madiun Residency. The results showed that all hypotheses proposed in this study were accepted. Security is the main requirement for people to continue or discontinue using fintech services. Perceived value is a comparative result influenced by the amount of sacrifice that is given and the perceived benefits. People who are satisfied and tends to assume that the fintech service is valuable, will most likely continue using the fintech service. Therefore, it can be concluded that TAM, VAM, PAM and security perceptions are a unified whole in understanding one's behaviour in adopting technology such as fintech services.
\end{abstract}

Keywords-TAM; VAM; PAM; Security Perception; Fintech

\begin{abstract}
Abstrak
Penelitian ini bertujuan untuk mengembangkan TAM (Technology Acceptance Model) dengan mengintegrasikan VAM (Value-based Adoption Model), PAM (Pos Acceptance Model) dan persepsi keamanan. Berdasarkan kerangka kerja ketiga teori tersebut diharapkan bisa menjelaskan secara lebih mendalam prespektif yang dirasakan pengguna layanan fintech, baik dari segi keamanan, perspektif nilai yang dirasakan, kegunaan dan kepuasan dalam menggunakan fintech. Desain penelitian yang digunakan dalam penelitian ini adalah survei melalui pendekatan kuantitatif dengan jenis explanatory research di Karesidenan Madiun. Hasil penelitian menunjukkan bahwa semua hipotesis yang diajukan dalam penelitian ini diterima. Keamanan merupakan syarat utama seseorang akan terus menggunakan atau tidak didalam menggunakan layanan fintech. Nilai yang dirasakan merupakan sebuah hasil komparatif yang dipengaruhi oleh besarnya pengorbanan yang dilakukan dan manfaat yang dirasakan. Seseorang yang harapannya dikonfirmasi lebih puas dan cenderung menggap layanan yang ada pada fintech berharga, maka pada akhirnya akan memiliki kecenderungan untuk melanjutkan menggunakan layanan fintech tersebut. Jadi bisa disimpulkan bahwa TAM, VAM, PAM serta persepsi keamanan merupakan satu kesatuan yang utuh didalam memahami perilaku seseorang dalam adopsi technologi dalam hal ini menggunakan layanan fintech.
\end{abstract}

Kata kunci-TAM; VAM; PAM; Persepsi Keamanan; Fintech

\section{INTRODUCTION}

The industrial revolution has reached a new stage known as the 4.0 industrial revolution. The main element of this industrial revolution is smart manufacturing which enables global network integration in cyber systems or Cyber-Physical Systems (Kagermann, 2013). This sophisticated technology brings a new era to the business sector, such as digitalization of financial and non financial sector of business processes. A variety of new products and services have emerged from this digitalization effect, for instance the emergence of digital 
advisory and trading systems, peer to peer (P2P) loans, crowdfunding, cellular payment systems and digital money such as bitcoin and srypto assets. This change has changed all aspects of life such as social, culture, economic system, lifestyle and others (Hun, et.al, 2018).

The growth and development of technological innovation has changed all systems from traditional to digital services. Including in financial sector where financial services and technology are closely interrelated. The application of science and technology have produced the vitality of modern financial service (Arner, et al, 2017). one example of technological innovation in financial services is fintech which has changed the existing business model and framework rules. The speed of technological innovation in the financial sector has shortened the financial services (Chiu, 2016), thereby reducing the costs between fund providers and those who need them, therefore increases efficiency, and lowers financial service costs (Salo \& Haapio, 2017)

Behind Fintech's financial services which offer effectiveness and efficiency, there are a number of major concerns from users' perspectives regarding the recording of financial transactions and the leakage of personal data for illegal use (Lim, 2016). Fintech has not changed the characteristics of external risk, technical risk, operational risk and systemic risk (Yang \& Li, 2018). In the past few years, the public has been shocked by the personal data leakage of Facebook users into Cambridge Analytica, which has resulted in criticism from the world and the decline in Facebook stock prices. This data leakage scandal has made the public questioned the security of fintech usage. In addition, the benefits, satisfaction and perceived value have affected people's perception in using fintech service.

TAM (Technology Acceptance Model) was introduced by Davis (1989) which is widely used in explaining the reason behind someone's decision in using a certain technology. TAM assumes that the reason for someone to adopt a certain technology is influenced by the technological factors such as design, features, convenience, and function (Kwon \& Seo, 2013). However, TAM has a limitation in explaining the someone's acceptance in receiving new technology. TAM does not consider the customers' perspectives, such as value and security, which theoretically, the consumer will always try to maximize the value obtained by sacrifices that have been made. In addition, the ability of TAM to explain the behavior of consumers to buy, use or accept a technology is quite weak (Hai \& Kazmi, 2015). Moreover, TAM has not been able to explain the social influence, facilities, and the available infrastructure (Torres \& Gerhart, 2017).

Kim, et al, (2007) introduced the Value-based Adoption Model (VAM) to illustrate the comparison value received by consumers with their sacrifices that have been previously made. Kim believes that there is a certain important relationship between the value felt by the customers and consumer decision to adopt a certain technology. Someone will use a technology if he can feel the benefits of a better value with all the sacrifices he had made in order to use the technology. Bhattacherjee, (2014) in his study stated that the intention to reuse a certain system of information (SI) was influenced by satisfaction in using the information system and the benefits they received, in turn the benefits obtained were influenced by confirmation of their expectations from the previous use of SI. This model is then called the Post Acceptance Model (PAM). The novelty of this research is the integration of the three theories, TAM, VAM, PAM and security perception, so that it will provide a deeper explanation of the intention to use fintech from various dimensions.

The novelty of this research generally lies in the aspects of psychomotor studies or the behavior of fintech service users. Various studies on fintech services starting from Arner, et al, (2017), Chiu, (2016), Yang \& Li, (2018), Bansal (2017), Hun et al., (2018) only discuss aspects of cognition, perception, and people's motivation for the presence of fintech services. The respondents studied are the users of fintech services, but actually they did not know fintech service in detail. In terms of research objects, Aboelmaged, (2013), Tan, et al. (2014), Teo, et al. (2015), Turel, et al. (2010), Ooi \& Tan, (2016), Johnson, et al. (2018) use M Payment and M Banking, while the object of this research is focused on the users fintech.

Early models of consumer behavior in using technology, for example, TAM developed by (Davis, 1989), VAM developed by Kim, et al (2007), PAM developed by Bhattacherjee (2014) is a model that combines behavioral and cognitive approaches. However, these models have problems, for example, the model ignores security perceptions, user motives. Consumptive behavior is influenced by stimuli or the external environment and the result of mental processes.

Thus, this study is quite argumentative, to develop TAM by integrating with VAM, PAM and security perception that has been developed by Davis (1989), Kim et al (2007), Hun et al (2018) and Bhattacherjee (2014). The results of this study are expected to strengthen and enrich the results of previous research findings, as well as complete the other research result, especially in the behavioral aspects of fintech service users. Based on the theoretical frameworks, it is hoped to be able to deeper explain the perspectives of fintech service users, whether it is from security, value perspective, benefits or satisfactory in using fintech. 


\section{LITERATURE REVIEW AND HYPOTHESIS DEVELOPMENT}

\section{A. Fintech}

Fintech is a new financial service using informational technology such as Internet of Things (IoT). Financial companies are able to improve their business process performance through fintech and provide innovative financial service to the customers (Hun et al., 2018). The fintech development is inseparable from the shift of offline financial services to cellular services, social networking, massive data and technology of cloud. As a result, services of payment and such technologies have rapidly developed beyond the limits of banking financial services that have existed so far.

\section{B. Technology Acceptance Model (TAM)}

Technology Acceptance Model (TAM), a development of the Theory of Reasoned Action (TRA) that seeks to interpret someone's reason to accept a certain technology which influenced by the perception of benefits and convenience (Fishbein, 1975; Davis, 1986; Davis, 1989). TAM is commonly used in research regarding the acceptance of a technology (Mallat, et al., 2009) and in marketing (Ahn, Ryu, \& Han, 2004). Davis (1989) states that benefit perception and accessibility are determinants factor of someone's intention in accepting or rejecting the technology. The benefit perception is defined as the extent to which someone's positives believes that his works' performance will significantly improve after using the technology. therefore, it can be interpreted that someone's intention to use a certain technology is ultimately driven by the perception of the benefit and accessibility of the technology.

Many researchers claim that perception of benefits significantly influences a person's intentions to adopt a certain technology. Kleijnen, (2004) conducted a study of 203 respondents who stated that benefit perception affected the intention to use Wireless Finance. Alsajjan \& Dennis, (2010) conducted a study of 618 students in Saudi Arabia and United Kingdom stating that benefit perception affected the students' intention to obtain benefit from using internet banking. The same thing was also reported by Aboelmaged, (2013) which stated that the benefit perception influenced the use of M Banking by 119 students in Dubai. Tan, et al, (2014) conducted a study with several respondents totaling 156 bank customers in Malaysia who stated that benefit perception affected the intention of using mobile credit card. Teo, (2015) in his study also concluded that the benefit perception especially time efficiency and portability affected the use of M payment.

\section{Value-based Adoption Model (VAM)}

The value base adoption model (VAM) was developed by Kim et al. (2007) who states that the TAM introduced by Davis has some limitations in explaining the acceptance of users regarding new technologies, especially for technology which requires users to pay acertain sum in using it. Kim et al., (2007) believes that new technology users should be seen, not only as users but also as consumers. TAM aims to explain someone's intention in using technology based only on the perception of benefit and convenience. On the other hand, VAM sees the cost paid and the benefits obtained by someone as some factors that influence someone in adopting a certain technology. Woodruff, R, (1997) states that the perception of value perceived by consumers influences their choice of using or rejecting a product according to their preferences. Turel, et al, (2010) conducted a survey of 422 ringtones users who states that perception of value perceived by consumers would positively and significantly affect their intention in using a product.

\section{Post Aceptance Model (PAM)}

The Post Acceptance Model (PAM) was developed based on the ECT introduced by (Oliver, 1980). PAM explains about consumer behavior at the level of customer satisfaction before (for example, consumer expectations for a product) and after making a purchase (for example, perceived satisfaction and intention to make the next purchase). Then later (Bhattacherjee, 2001) in his study stated that people intention to continue or to halt the use of a certain technology is influenced by the satisfaction and benefits felt by users in using the technology. 


\section{E. Security Perception}

One of the main issues in fintech is security. Potential users of fintech services must share their personal data information with service providers. The security perception of a technology users is a cognitive process that will affect someone's intention to use a certain technology (Bhattacherjee, 2001). Vatanasombut, et al. (2008) state that security perception is the safe feeling perceived by users in using a certain platform. In the consumer perspective, the security of a technology system is the ability of the intended technology to protect personal data or information from various threats, fraud and theft or improper use of personal data (Hun et al., 2018). Thus, it can be concluded that if the customers feel secure in using the technology, then the consumer will be willing to open his personal information and make transactions.

Ooi \& Tan, (2016) conducted a study with one of the conclusions stating that security perception is the main factor for a person who intends to use the features of application available on their mobile, such as credit cards and other features. Bansal (2017) states that security is a wall which builds indirect trust in all forms of electronic transactions, which can trigger user intentions to share personal information with a website. Johnson, et al. (2018) also conveys that security felt by users influences someone to use mobile payment. Similar sentiment was also conveyed by Hun et al., (2018) who stated that the security perception perceived by users had a significant effect on the perception of benefits felt by users but gave no direct effect on their intention to use the fintech service application.

F. Hypothesis

H1 : Security perception significantly influence the intention in using fintech.

H2 : Security perception significantly influence the perception of benefits.

H3 : The perception of benefits significantly influences the perception of value.

H4 : The perception of benefits significantly influences the perception of satisfaction.

H5 : The perception of value significantly influences the intention in using the fintech service.

H6 : The perception of benefit significantly influences the intention of using fintech service.

H7 : The satisfaction significantly influences the intention of using fintech service.

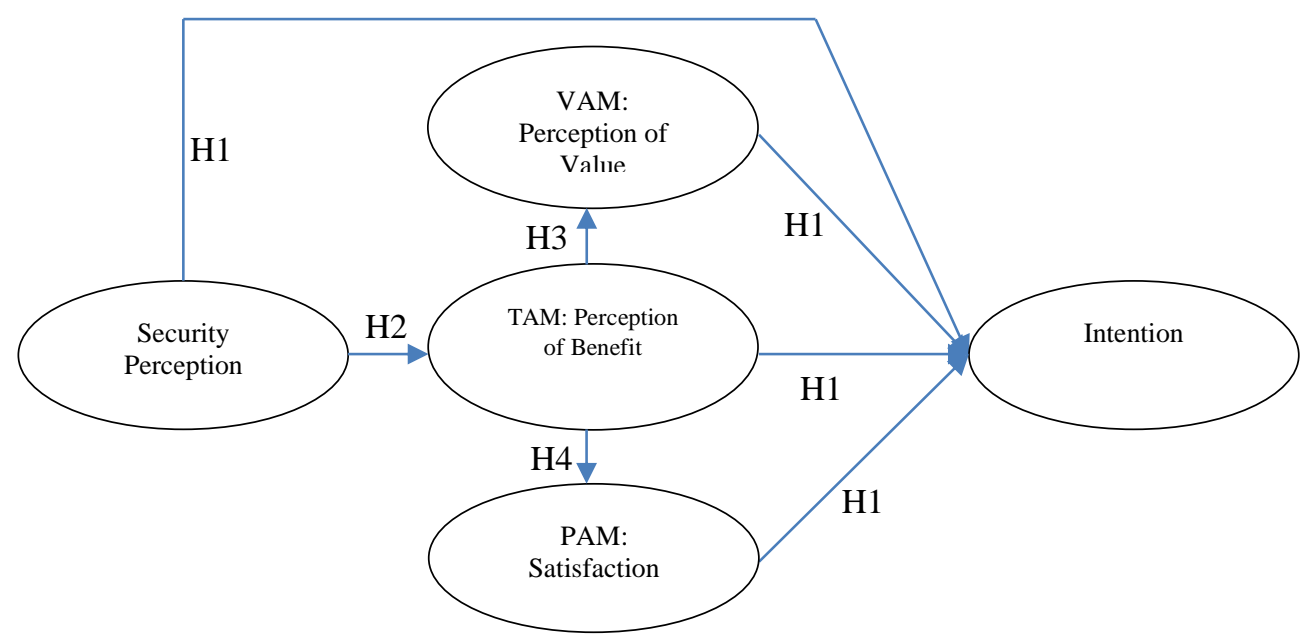

Fig. 1. Hypothesis Framework 


\section{METHODOLOGY}

\section{A. Research Design}

This research is a survey research through a quantitative approach with the type of explanatory research. This study uses primary data obtained from questionnaire distribution containing a list of questions related to fintech services, perception of satisfaction, benefit, security and value modified from the research of Bhattacherjee (2001) and Kim, et al. (2019), and a modified security perception from Hun et al. (2018). The questionnaire used in this study consisted of two important parts. The first contains demographic information and the background of the respondents while the other consists of some items that measure the construct. A five-point Likert scale is used, with the lowest score being Strongly disagree (1) and the highest score is strongly agree (5). Questionnaires were carefully examined including the participant's explanation on the study purpose. Secondary data is obtained from reference books which are relevant to this study. The study took place in Madiun Residency from September to November 2019.

\section{B. Population, Sample, and sampling Technique.}

This Study uses 176,000 people of productive age in the Madiun Recidency. The purposive sampling is used in this study, with criteria: 1) respondents aged 18-50 years. 2) have done transactions with fintech. The Slovin formula is used in determining the sample's size and as many as 399 respondents were obtained.

\section{Data Analysis}

The quantitative descriptive analysis is used for analyzing the data, while the construct validity with Confirmatory Factor Analysis were used to confirm the data validity, which variable is said to be valid if the KMO value> 0.5 (Ghozali, 2013). Meanwhile, the one shot with the Cronbach Alfa statistical test is used to determine the reliability of data in this study. A construct is said to be reliable if the Cronbach Alpha value> 0.70 (Nunnally, 1978). After the process of validity and reliability of each contract, data analysis was performed using the help of AMOS 21 software with the SEM equation model.

\section{IV.RESULT AND DISCUSSION}

\section{A. Respondent Characteristics.}

Upon conducting research by distributing questionnaires to 399 respondents, tabulation of data was conducted to determine the characteristics of respondents and group them by sex/gender, age and frequency of using fintech service as shown by Table 1 .

Table 1. Respondent Demography Analysis

\begin{tabular}{llll}
\hline Variable & Category & Frequency & Percentage (\%) \\
\hline Sex/gender & Male & 168 & $42 \%$ \\
& Female & 231 & $58 \%$ \\
age & $18-25$ Years old & 139 & $35 \%$ \\
& $26-33$ Years old & 128 & $32 \%$ \\
& $34-41$ Years old & 68 & $17 \%$ \\
& $42-49$ Years old & 44 & $11 \%$ \\
Frequency in using Fintech & $1-4$ times/year & 20 & $5 \%$ \\
service & 88 & $22 \%$ \\
& $5-10$ times/year & 159 & $40 \%$ \\
& $\geq 10$ times/year & 152 & $38 \%$
\end{tabular}

Table 1 proves that the women use fintech services $16 \%$ more frequently than men, where female shown to be using $58 \%$, while female only $42 \%$. This is due to the tendency of Indonesian women to be in control of family finances, and they have more time to do financial transactions compared to men. Seen from age criteria of the respondents, the majority of fintech services users are dominated by respondents aged 18-25 years old 
with $32 \%$, followed by ages $26-33$ years old with $32 \%$, ages $34-41$ years old with $17 \%$, and respondents aged 42 - 49 years with $11 \%$, while respondents aged above 59 years old are only $5 \%$. This shows that younger respondents interact more with fintech services compares to their older counterparts. Hun et al., (2018) states that the millennial generation is the main driver of the global digital economy intersecting with technologies such as artificial intelligence, and so on. Whereas based on the frequency of using fintech, most respondents used fintech more than 10 times in one year which showed that modern people prefer practicality in every financial transaction.

\section{B. Reseach Instruments Test}

The purpose of conducting an instrument test in this study is to measure whether the research instrument has fulfilled the requirements, by reducing the valid data, according to the rules of scientific research. The first step conducted was to test the data validity through the confirmatory factor analysis (CFA) test, using the Kaiser Meyer Olkin tool, with the desired value of $>0.05$. The results of the construct validity test shows that the KMO value is 0.714 which shown that the analysis of the factors can be performed. The Bartlett test value with Chi-square result of 184,768 and significant at 0,000, which means that the factor analysis test can be continued.

The second step is to conduct a reliability test with the Cronbach Alfa statistical test of each instrument. To obtain reliability, the Cronbach Alpha value must be> 0.70 (Nunnally, 1978). The SPSS output result proves that all constructs of the study are reliable. the result shows that the value of the variable safety perception was $78.3 \%$, Perception of benefits was $81.1 \%$, perception of value was $75.4 \%$, perception of satisfaction was $77.4 \%$ and intention was $79.3 \%$

\section{Data Validity Evaluation}

Prior conducting a statistical test of the hypotheses using SEM, the first step to be conducted is to scan the data through the normality test by looking at the value of the critical ratio of skewness and kurtosis. Ghozali (2013) states that if the variable is normally distributed, then the value of skewness and kurtosis is equal to zero, for alpha 0.05 the critical value is \pm 1.96 . The calculation results of $Z$ value on all variables in this study, the critical value above 1.96 is produced with significant at $\mathrm{a}=0.05$. Thus, all variables in this study are normally distributed.

The second step is to detect outlier data. Outliers test in this study uses criteria at the level of $\mathrm{p}<0.001$. Mahalanobis distance was evaluated using X2 at a free degree equal to the number of indicator variables used in the study of (Ghozali 2013). Upon conducting the outlier test, the inconsistent data removal is performed by reducing 5 values to remove the outliers.

\section{Goodness of fit Test}

According to Ghozali (2013), analysis using SEM has no single statistical test instrument to measure or to test the hypothesis regarding the model. Generally, there are various forms of fit Index used in measuring the suitability degree among models hypothesized with data. The model will be tested by comparing some fit index values. This test is meant to measure the correctness of the proposed models. The results of the suitability index test and its cut-off value are shown in Table 2.

Table 2. Goodness of Fit Test Result of The Research Model

\begin{tabular}{lccc}
\hline \multicolumn{1}{c}{ Goodness of Fit index } & Cut Off Value & Result of Analysis & Information \\
\hline$x^{2}-$ Chi Square & & 878.033 & \\
Probability & $\geq 0,05$ & 0.340 & Good \\
CMIN/df & $<2 /<3$ & 2.045 & Good \\
$R M R$ & $<0,03$ & 0.073 & Marginal \\
GFI & $\geq 0.90$ & 0.956 & Good \\
AGFI & $\geq 0.90$ & 0.931 & Good \\
$T L I$ & $\geq 0.90$ & 0.969 & Good \\
CFI & $\geq 0.90$ & 0.946 & Good \\
$R M S E A$ & $\leq 0,08$ & 0.006 & Good
\end{tabular}

Based on the goodness of fit test result, it shows the results of (Chi-square $=878,033)$. The value of X2 / df (Chi-square / Degrees of freedom) is 2,045, which is 3 less than the outlier value (Bollen, 1990). The GFI 
value is 0.956, while the AGFI is 0.931 (Tabachnick \& Fidell, 2006), the TLI is 0.969 (Byrne, 1998), and the CFI is 0.946, (Bollen, 1990). on the other hand, the RMSEA value is 0.063 which is 0.08 below the outlier value (Maccallum, et al, 1996).

\section{E. Hypothesis Test}

The structural equation model is used in testing the proposed hypotheses with the help of Amos 21 software. The results of the hypothesis test are presented in Table 3

Table 3. Maximimum Likehood Estimate

\begin{tabular}{|c|c|c|c|}
\hline Hypothesized parts & $\begin{array}{l}\text { Standardized } \\
\text { Path Estimate }\end{array}$ & $\begin{array}{l}\text { Critical } \\
\text { Ratio (t } \\
\text { value) }\end{array}$ & Hypothesis \\
\hline Perception of Security $\leftarrow$ intention & $0.230 * *$ & 3.283 & Accepted \\
\hline Perception of Security $\leftarrow$ Perception of benefits & $0.860 * * *$ & 13.160 & Accepted \\
\hline Perception of benefit $\leftarrow$ Perception of value & $0.381 * *$ & 7.807 & Accepted \\
\hline Perception of benefit $\leftarrow$ Satisfaction & $0.923 * * *$ & 13.631 & Accepted \\
\hline Perception of value $\leftarrow$ Intention & $0.415 * * *$ & 5.367 & Accepted \\
\hline Perception of benefit $\leftarrow$ intention & $0.140 * * *$ & 2.744 & Accepted \\
\hline Satisfaction $\leftarrow$ Intention & $0.167 * * *$ & 2.267 & Accepted \\
\hline
\end{tabular}

Table 3 shows that Hypothesis 1 is accepted, which means that security perception significantly influences the intention to use fintech with a value $(b=0.230, t=3.283)$, the safety factor is a fundamental reason considered by fintech users. If someone feels safe in using fintech services, someone will have the tendency to continue using the fintech services and vice versa. On the other hand, if fintech services users feel that the risk is higher compares to the benefits, they will be motivated to avoid or reject using the fintech services. From consumer perception, security is the service quality provided by the providers to ensure that the consumers are free from any risks and losses (Ray, 2011).

Table 3 also shows that $\mathrm{H} 2$ is accepted. This means that security perception significantly influences the perception of benefit with a value of $(b=0.860, t=13.160)$. In adopting a new device, using fintech services, someone will evaluate whether adopting the device will be proportional to the level of risks and benefits felt after using fintech services.

The next result shows that hypothesis 3 is accepted. It means that there is significant effect given by the benefit perception on the perception of value, i.e. $(b=0.381, t=7.807)$, Consumers' perception of value is the value obtained by consumers from comparing the costs incurred to the benefits received in using fintech services. The greater the value felt by the consumer, the higher the perception of benefits. The result is in rhyme with research conducted by (Kim et al., 2007) in his study of mobile internet which states that the perception of benefit affects the perception of value. Teo et al., (2015) states that using electronic payments could save more time and is more efficient. Zeithaml, (2012) states that the perception of value is a consumer's subjective evaluation based on the trade between the costs of goods or service and the benefits. The definition of perception of value by Zeithaml, (2012) is commonly used to indicate overall evaluation given by consumers on the benefit of a certain product (Lin, et al., 2012).

The data which shows that hypothesis 4 is accepted means that the perception of benefits significantly influent the perception of satisfaction $(b=0.923, t=13.631)$. Some previous studies also showed that evaluations on the perception of benefit and sacrifice affect a perception of satisfaction and costumers' intention on using the service continuously. Lee, (2010) states that the level of perception of benefits affects satisfaction and therefore could affect the students' intention on using E-learning. Likewise, other studies have shown that the perception of benefits are determinants of satisfaction and continuous intention (Kim, 2011). Oliver (1988) states that many marketing studies state that high expectations effect high satisfaction. The results supported the function of VAM in explaining someone's intention in adopting a certain technology.

The fact that hypothesis 5 is accepted shows that perception of value has a significant effect on the costumers' intention in using fintech services $(b=0.923, t=13,631)$. Perception of value is an assessment of the perceived benefits and the costs incurred. Therefore, someone who feels that they receive a higher value from using a certain technology service provider it will be more likely for them to increase their intention in adopting the technology. This result supports the researcher (Roostika, 2012) who states that the perception of value influences the intention of someone to use a mobile internet provider.

The next data presented by table 3 shows that hypothesis 6 is accepted. Perception of benefit significantly influences the intention in using the fintech services $(b=0.415, t=5,367)$. A person will always evaluate their behavior in every decision making. If someone feels that using a certain technology can provide high benefits, 
it will increase their intention in using the technology. This is in accordance with the research conducted by (Kim et al., 2007) which states that the perception of benefits affects someone's intention in using technology.

The last discussion is about the hypothesis 7 which is accepted. It shows that satisfaction significantly influences intention to use fintech $(b=0.140, t=2.744)$ which can be concluded that the higher a person is satisfied in adopting a certain technology, the higher their tendency to continuously use the technology. (Bhattacherjee, 2001) proposed the ECM concept regarding the decisions on using IT and the decision to repurchase them. ECM believes that someone's intention to use IT depends on the level of satisfaction upon adoption, in the form of the perceived benefits.

\section{CONCLUSION}

All hypotheses proposed in this study were accepted. The result shows that security is the main requirement for someone to continue using fintech services. Perception of value is a comparative result influenced by the amount of sacrifice that has been made and the perceived benefits. Someone whose hopes are fulfilled by fintech is confirmed to be more satisfied and tends to assume the fintech service is valuable, which will generate their tendency to continue using the fintech service. Therefore, it can be concluded that TAM, VAM, PAM and security perceptions are a unified whole in understanding someone's behavior in adopting technology such as fintech services.

Based on the theoretical perspective, VAM is considered to consider the sacrifices that have been ignored by TAM, while PAM is a theory that explains someone's satisfaction upon purchasing which influence the decision of repurchasing. Therefore, it theoretically imply a deeper understanding of sustainable intentions in using fintech services. Academically, design and result implication of this study expand the scope of research on fintech services. Therefore, the theoretical framework proposed and tested in this study is suggested to be used as a basis for further research.

Practical implication of the perception of value, satisfaction, and security must be improved in providing fintech services. To encourage users of fintech services to continue using the services provided. It is important to continue to focus on the benefits provided by the service provider to maintain the data security of the users.

\section{REFERENCES}

Aboelmaged, M., \& Gebba, T. R. (2013). Mobile Banking Adoption: An Examination of Technology Acceptance Model and Theory of Planned Behavior. International Journal of Business Research and Development, 2(1), 35-50. https://doi.org/10.24102/ijbrd.v2i1.263

Ahn, T., Ryu, S., \& Han, I. (2004). The Impact Of The Online And Offline Features On The User Acceptance Of Internet Shopping Malls. Electronic Commerce Research and Applications, 3, 405-420. https://doi.org/10.1016/j.elerap.2004.05.001

Alsajjan, B., \& Dennis, C. (2010). Internet Banking Acceptance Model: Cross-Market Examination. Journal of Business Research, 63(9-10), 957-963. https://doi.org/10.1016/j.jbusres.2008.12.014

Arner, D. W., Barberis, J., Buckley, R. P., Arnott, R. D., \& Aronson, T. R. (2017). Foundation Briefs Fintech And Regtech In A Nutshell, And The Future In A Sandbox. Research Foundation Briefs, Volume 3(Issue 4).

Bansal, G. (2017). Distinguishing Between Privacy And Security Concerns: An Empirical Examination And Scale Validation. Journal of Computer Information Systems, 57(4), 330-343. https://doi.org/10.1080/08874417.2016.1232981

Bhattacherjee, A. (2001). Understanding Information Systems Continuance: An Expectation-Confirmation Model. MIS Quarterly, 25(3), 351-370.

Bhattacherjee, A. (2014). Qarterjy CONTINUANCE : Management Information Systems Research Center, 25(3), 351-370.

Bollen, K. A. (1990). Overall Fit in Covariance Structure Models: Two Types of Sample Size Effects. Psychological Bulletin, 107(2), 256-259. https://doi.org/10.1037/0033-2909.107.2.256

Byrne, arbara M. (1998). Structural Equation Modeling With Lisrel, Prelis, and Simplis (1st Editio). New York: Psychology Press.

Chiu, I. H.-Y. (2016). Fintech And Disruptive Business Models. Journal Of Technology Law \& PolicY, 21, 55112.

Davis, Jr., F. D. (1986). A Technology Acceptance Model For Empirically Testing New End-User Information Systems: Theory And Results [Dissertation]. https://doi.org/10.1016/S0378-7206(01)00143-4

Davis, F. D. (1989). Perceived Usefulnees, Perceived Ease of Use, and User Acceptance of Information 
Technology. MIS Quarterly, 13(3), 319-340. https://doi.org/10.1016/S0305-0483(98)00028-0

Fishbein, M., \& Ajzen, I. (1975). Belief, Attitude, Intention, and Behavior: An Introduction to Theory and Research. USA: Addison-Wesley.

Ghozali, I. (2013). Aplikasi Analisis Multivariate dengan program IBM SPSS 21. Semarang: Badan Penerbit Universitas Diponegoro.

Hai, L. C., \& Kazmi, S. H. A. (2015). Dynamic Support of Government in Online Shopping. Asian Social Science, 11(August). https://doi.org/10.5539/ass.v11n22p1

Hun, S., Kim, D. J., Hur, Y., \& Park, K. (2018). An Empirical Study of the Impacts of Perceived Security and Knowledge on Continuous Intention to Use Mobile Fintech Payment Services. International Journal of Human - Computer Interaction.

Johnson, V. L., Kiser, A., Washington, R., \& Torres, R. (2018). Limitations To The Rapid Adoption Of MPayment Services: Understanding The Impact Of Privacy Risk On M-Payment Services. Computers in Human Behavior, 79, 111-122. https://doi.org/10.1016/j.chb.2017.10.035

Kagermann, H. (2013). Securing the future of German manufacturing industry initiative INDUSTRIE 4.0 implementing the strategic Recommendations for Final report of the Industrie 4.0 Working Group.

Kim. (2011). Understanding Antecedents of Continuance Intention in Social-Networking Services. Cyber Psychology,Behavior, And Social Networking, 14(4). https://doi.org/10.1089/cyber.2010.0009

Kim, H., Chan, H. C., \& Gupta, S. (2007). Value-Based Adoption Of Mobile Internet: An Empirical Investigation. Decision Support Systems, 43, 111-126. https://doi.org/10.1016/j.dss.2005.05.009

Kim, S. H., Bae, J. H., \& Jeon, H. M. (2019). Continuous Intention on Accommodation Apps : Integrated ValueBased Adoption and Expectation - Confirmation Model Analysis. Sustainabi, 1-17. https://doi.org/10.3390/su11061578

Kleijnen, M., Wetzels, M., \& de Ruyter, K. (2004). Consumer Acceptance Of Wireless Finance. Journal of Financial Services Marketing, 8(3), 206-217. https://doi.org/10.1057/palgrave.fsm.4770120

Kwon, H., \& Seo, K. (2013). Application of Value-based Adoption Model to Analyze SaaS Adoption Behavior in Korean B2B Cloud Market. 5(12), 368-373.

Lee, M. (2010). Computers \& Education Explaining And Predicting Users' Continuance Intention Toward ELearning : An Extension Of The Expectation - Confirmation Model. Computers \& Education, 54(2), 506516. https://doi.org/10.1016/j.compedu.2009.09.002

Lim, S. H. (2016). 전자메일 서비스 이용자의 패스워드 교체 심리에 대한 연구 An Investigation of the Psychology of Password Replacement by Email Users. Journal of The Korea Institute of Information Security \& Cryptology, 26(5).

Lin, T. C., Wu, S., Hsu, J. S. C., \& Chou, Y. C. (2012). The Integration Of Value-Based Adoption And Expectation-Confirmation Models: An Example Of IPTV Continuance Intention. Decision Support Systems, 54(1), 63-75. https://doi.org/10.1016/j.dss.2012.04.004

Maccallum, R. C., Browne, M. W., \& Sugawara, H. M. (1996). Power Analysis And Determination Of Sample Size For Covariance Structure Modeling Of Fit Involving A Particular Measure Of Model. Psychologycal Methods, 13(2), 130-149.

Mallat, N., Rossi, M., Tuunainen, V. K., \& Anssi, O. (2009). Information \& Management The Impact Of Use Context On Mobile Services Acceptance: The Case Of Mobile Ticketing §. Information \& Management, 46, 190-195. https://doi.org/10.1016/j.im.2008.11.008

Nunnally, J. C. (1978). Psychometric theory (2nd Editio). New York: McGraw Hill.

Oliver, R. L. (1980). A Cognitive Model of the Antecedents and Consequences of Satisfaction Decisions. Journal of Marketing Research, 17, 460-469. https://doi.org/10.11113/jt.v56.60

Oliver, R. L., \& Desarbo, W. S. (1988). Response Determinants in Satisfaction Judgments. THE JOURNAL OF CONSUMER RESEARCH, 14(March), 495-507.

Ooi, K. B., \& Tan, G. W. H. (2016). Mobile Technology Acceptance Model: An Investigation Using Mobile Users To Explore Smartphone Credit Card. Expert Systems with Applications, 59, 33-46. https://doi.org/10.1016/j.eswa.2016.04.015

Ray, S. (2011). Security Assurance: How Online Service Providers Can Influence Security Control Perceptions and Gain Trust. Decision Science, 42(2), 391-412.

Roostika, R. (2012). Mobile Internet Acceptance among University Students : A Value-based Adoption Model. International Journal of Research in Management \& Technology, 2(1), 21-28.

Salo, M., \& Haapio, H. (2017). Robo-Advisors And Investors : Enhancing Human-Robot Interaction Through Information Design : International Legal Informatics Symposium IRIS 2017, 441-448.

Tabachnick, B. G., \& Fidell, L. S. (2006). Using Multivariate Statistics (5th Edition). Boston: MA : Allyn and 
Bacon.

Tan, G. W. H., Ooi, K. B., Chong, S. C., \& Hew, T. S. (2014). NFC Mobile Credit Card: The Next Frontier Of Mobile Payment? Telematics and Informatics, 31(2), 292-307. https://doi.org/10.1016/j.tele.2013.06.002

Teo, A. C., Tan, G. W. H., Ooi, K. B., \& Lin, B. (2015). Why Consumers Adopt Mobile Payment? A Partial Least Squares Structural Equation Modelling (PLS-SEM) approach. International Journal of Mobile Communications, 13(5), 478-497. https://doi.org/10.1504/IJMC.2015.070961

Torres, R., \& Gerhart, N. (2017). Mobile Proximity Usage Behaviors Based on User Characteristics Mobile Proximity Usage Behaviors Based on User Characteristics. Journal of Computer Information Systems, 00(00), 1-10. https://doi.org/10.1080/08874417.2017.1320954

Turel, O., Serenko, A., \& Bontis, N. (2010). User Acceptance Of Hedonic Digital Artifacts: A Theory Of Consumption Values Perspective. Information and Management, 47(1), 53-59. https://doi.org/10.1016/j.im.2009.10.002

Vatanasombut, B., Igbaria, M., Stylianou, A. C., \& Rodgers, W. (2008). Information Systems Continuance Intention Of Web-Based Applications Customers: The Case Of Online Banking. Information and Management, 45(7), 419-428. https://doi.org/10.1016/j.im.2008.03.005

Woodruff, R, B. (1997). Customer Value The Next Source For Competitive Advantage. Journal of the Academy of Marketing Science, 25(2), 139-153.

Yang, D., \& Li, M. (2018). Evolutionary Approaches and the Construction of Technology-Driven Regulations. Emerging Markets Finance \& Trade, 1-16.

Zeithaml, V. A. (2012). Consumer Perceptions of Price, Quality, and Value: A Means-End Model and Synthesis of Evidence. Journal of Marketing, 52(3), 2-22. 